November - 2004

\title{
Use of Distance Education by Religions of the World to Train, Edify and Educate Adherents
}

\author{
P. Clint Rogers and Scott L. Howell \\ Brigham Young University \\ USA
}

\begin{abstract}
Islamic, Hindu, Buddhist, Baha'i, Jewish, and Christian organizations are all experimenting with distance education for various reasons and to different extents, due to religious, economic, and political factors. Religious institutions worldwide are not only turning to the World Wide Web (WWW) to place information concerning religious beliefs and provide virtual services for their constituents but are also getting more involved in formally educating their members at a distance. This paper will document some of these educational efforts and the reasons behind the expanding use of distance education by several of the major religious institutions for training, edifying, and educating their religious adherents.
\end{abstract}

Keywords: distance education; distance learning; religion; religious education and training; religious institutions; theology

Acknowledgments: Special thanks to Rachel A. Rowe, our research assistant; Dr. Dwight Laws, director of Brigham Young University (BYU) Department of Independent Study; and the BYU Division of Continuing Education who sponsored this research.

\section{Introduction}

In his book, The Soul of Cyberspace: How New Technology Is Changing Our Spiritual Lives, Jeffrey P. Zaleski points out that the online world "is a world of mind alone." He asks some poignant questions: "How will the human spirit fare in such a realm, sundered from the mystery of the flesh? . . . What effect does surfing the Web have on mind, on conscious, and, most importantly, on attention - the basic tool of spiritual realization? . . . Does cyberspace . . . present a particular challenge to spiritual work?” $(1997$, p. 6). These are the same questions that leaders and academics from most religious institutions have as they consider the opportunities and challenges associated in reaching out to their membership using distance learning models and technologies.

Religious institutions ${ }^{\underline{1}}$ from across the world appear to be developing and experimenting with distance learning for a variety of reasons and purposes. Even though "little has been written and published on distance education in North American theological education” (Amos, 1999, p. 126) as well as theological education at a distance worldwide, the trend to more religious use with and involvement in distance learning has become apparent to the authors. Accordingly, this paper is a 
synthesis of a literature review - which yielded little research in the area - and a significant amount of original research based primarily on interviews with religious leaders and academics associated with religious institutions involved in formal distance learning efforts.

Helland (2002) classified religions that use the Internet as either "religion-online" (simply presenting information about religion with limited participation) or "online-religion" (providing an interactive religious environment). These two classifications could include using the Internet as an information resource (by providing documents, services, directories, calendars, and specialized resources for religious use), for virtual worship services, to facilitate other types of online religious communication and communities, and even to proselytize non-adherents. For this article, the focus will remain on how religious institutions are increasingly using the Internet and distance education models to educate their adult membership as an organized, formal course of study - arguably a category all its own.

Those creating religious distance education programs identify the reasons for their efforts from simply desiring to keep pace with others, to fulfilling some kind of mission or purpose that is foundational to the religion's doctrine or credo. The polarization between faith and reason in a largely secular society has led some religious institutions to believe that distance learning may provide a way to bridge secular and spiritual gaps in the minds of learners by offering courses that seek to integrate the two.

This paper begins by providing background to the factors that have influenced the growth of religious institutions' use of distance education. Then it provides some examples of distance education efforts from many of the world's major religions and an examination of the catalyst(s) behind such efforts. The authors conclude by offering ideas about future trends in religious use of distance education and suggestions for additional research.

\section{Background}

How religions view both formal and informal education doctrinally, culturally, and traditionally can differ greatly from religion to religion and even within a religion, and thereby influence the use of distance education to train, edify, and educate its adherents. For the purposes of this paper, formal education is defined as an organized course of study that usually requires some kind of registration and often leads to a title, degree, or certificate. Most of the major religions of the world, in combination with other educational methods, support some form of formal education where instructors and learners are separated by time and space, with some kind of communication medium (e.g., mail, Internet, etc.) to connect them.

Although religious institutions might use technology and the World Wide Web to support everything from internal communication to external proselytizing, religious applications of adult distance learning generally comprise an effort to extend religious-based instruction to three classes of constituents: 1) seminaries (primarily for the training and theological education of clergy $)^{\underline{2}}$, 2) university students attending church-sponsored or -affiliated universities and colleges, and 3) members of the laity in an effort to build faith, educate about doctrine, strengthen community, and extend other lifelong learning opportunities ${ }^{\underline{3}}$. The purposes and extent to which each religion has employed distance instruction to these groups of constituents will always be influenced by a number of political, economic, and religious factors. 


\section{Training Clergy and Laity}

Almost every major world religion has congregations and adherents both near and far in need of better trained clergy, or religious leaders. Various Islamic, Hindu, and Christian denominations have all attempted using some type of distance education model whereby the "lay ministry" (a member of the laity that is taking ministerial responsibilities) can receive continuing education wherever they may be practicing. Additionally, faculty and students alike at traditional brick-andmortar theological schools are exploring more flexible and blended instructional and distance delivery options to better meet the needs of non-traditional students and mobile faculty. Thus, many of the initial efforts of faith-based organizations to implement distance education programs have been primarily from seminaries for the theological training of clergy. This is changing, however, as "a growing literature base advocates theological education of the laity and a return to the importance of education of the whole people of God [regardless of whether they have ministerial responsibilities or not]" (Cannell, 1999, p. 54). For example, some of Buddhist organizations in Thailand and Sri Lanka now offer correspondence education courses where lay members can learn more about their faith and receive a certificate or diploma for completing course work (Dr. Lewis Lancaster, Personal Communication, March 16, 2004).

\section{Higher Education and Piety}

The scope of curricular content in distance education courses is also extending beyond strictly theological education, as more people of faith are placing value on receiving higher education. Dr. James Stewart, the associate dean in the School of Distributed Learning at Bethany College, sponsored by the Christian Assemblies of God organization, has noted a change in the focus of Christian educational efforts since about the 1960s. Prior to that time, he felt as "if there were almost an anti-education philosophy, that if you were educated then you weren't spiritual" (Personal Communication, February 9, 2004). The Encyclopedia of Protestantism (2004) corroborates this claim, outlining many periods in history when revivalists considered all forms of critical learning based on reason (and not faith) as a threat to piety. Some churches today (e.g., Jehovah's Witnesses, Amish, Mennonites, Hutterite Brethren) are still hesitant to encourage higher education, feeling it might distract from faithfulness as well as family and ministerial responsibilities.

Dr. Stewart has noticed, however, that most churches are beginning to see secular education integrated with religious values as being just as important in parishioners' preparation for their "life ministry" as the spiritual training. Prior to the 1960s, he said, it would have been rare to see a minister with a Bachelor degree, but now all church members are encouraged to pursue college education and even advanced degrees (Personal Communication, February 9, 2004). The emphasis on higher education by religious institutions can be seen in examples such as Andrews University (Seventh-Day Adventist), whose motto is "Educar es Redimir" (to Educate is to Redeem), and the fact that many church organizations have departments of Collegiate Ministries. Another example is the fastest-growing Christian church (Church Executive, 2004), The Church of Jesus Christ of Latter-day Saints, whose current leader, President Gordon B. Hinckley, told the youth of the church in a recent worldwide address: "You need all the education you can get. Sacrifice a car; sacrifice anything that is needed. . . You belong to a church that teaches the importance of education” (New Era, 2001, p. 4). Because distance learning can make more secular and spiritual educational opportunities accessible to more of their members and students "anytime, anywhere," many religious institutions are enlarging their role as an education provider, especially to their own constituency. Distance learning is one of the ways by which 
religious-affiliated universities and colleges are meeting this need to integrate the spiritual into the secular.

\section{Church and State}

In many areas of the world, as is the case with most of the Islamic countries, there is not a clear separation between church (or mosque, synagogue, etc.) and state, and no perceived separation between the spiritual and the secular. Similar to many Western countries of centuries past, these governments do not usually separate religious credos from legal decisions. That means that almost any educational effort within these countries is, in essence, the product of a religious institution. There are currently 58 member nations of the Organization of the Islamic Conference (OIC), which is the global intergovernmental organization of Islamic states (see http://www.islamicnews.org/english/index.html), each with different degrees of interest in and acceptance of distance education. Although Nasser and Abouchedid (2000) of Notre Dame University indicate that in many Arabo-Islamic countries (e.g., Lebanon): "Ministries of Education do not officially recognize higher education degrees obtained by distance” (p. 1), some Islamic organizations (from both Arabic and non-Arabic countries) are very interested in how distance learning can be used to "make Islamic culture the basis of educational curricula at all levels and stages" and "safeguard the Islamic identity of Muslims in non-Islamic countries" (Islamic Educational, Scientific and Cultural Organization, ISESCO, http://www.isesco.org.ma/English/presentation/present.html).

There has also been a trend in certain democratized countries, such as India (largely Hindu) and Turkey (largely Islamic), toward a more Western model of secular government. In these countries, religiously sponsored educational institutions, as a result of political and social influences, have often been marginalized (Dr. Ilhan Yildiz, Personal Communication, March 5, 2004) and lack much of the comparative prestige and resources that are helpful when exploring and expanding new and innovative educational models, such as distance education.

This marginalization of church-sponsored educational institutions by some governments also extends to communist societies. While some may argue that communism is itself a religion (McFarland,1998), religion in the traditional sense as well as any religious education - much less religious-sponsored general education - is still discouraged in communist states. For instance, although China has passed legislation to promote private universities, none of these private institutions claim to be affiliated with any religion (Dr. Jin Lin, Personal Communication, March 10, 2004).

In the Western world, countries like the United States of America have experienced a shift away from their religious influence toward a more pluralistic and secular influence in their statesponsored institutions. The dilemma of being taught one thing in the place of worship and another - and often contradictory - thing in the public school, is an intellectual and spiritual challenge that is common to students, especially in a secular society. The reaction to this trend has "led to an increas[e] in home schooling and private schooling, as well as legal battles over governmental regulations of public schools" (Encyclopedia of Protestantism, 2004, p. 649). This general polarization and compartmentalization of teaching only the secular out of a moral/ spiritual context in the public arena has caused some religious institutions to assume a greater role in the formal education of its membership. At the elementary and secondary levels (i.e.,K-12), Home Study International (7th Day Adventist), Kolbe Academy Home School (Catholic), and the Sycamore Tree Center for Home Education, are just a few of the many distance education 
providers that offer parents who home school their children a faith-centered curriculum that is nationally accredited in the United States.

\section{Competition and Quality of Education}

Aside from any religious or moral motivation, Cagney (1997, as cited in Cannell, 1999) gives a pragmatic recommendation for theological schools to start introducing distance education or face the risk of not keeping up with those who do. This observation was further supported in conversation with the director of collegiate ministries, United Church of Christ, who says most of their colleges are using distance education like any secular institution would, because "that is the way competition is" and that there is "very little religious motivation behind [their use of distance education]" (Steven Johnson, Personal Communication, March 8, 2004). But regardless of any influences that encourage religious-affiliated institutions to develop applications of distance learning, there is still a feeling among certain religious institutions that they should move more slowly in supporting such efforts, "until quality course design has been demonstrated, until a greater number of primary resource materials for theological disciplines are electronically accessible, and when the medium can prove that interactivity is possible and effective" (Cannell, 1999, 54; see also Bellinger, 2003; Crosby, 1997).

The authors believe that many of these barriers to adoption and concerns about design, resource materials, and interactivity have been mitigated by technological and pedagogical progress in distance education the past five years. Furthermore, great strides have been made in establishing standards and determining how best to assess and support quality instruction in this new teaching environment (McLoughlin and Luca, 2003). Many religious institutions have established an educational strategic plan that includes distance education, and now is the time for many others to do the same as distance education models mature and best practices emerge. Quality course design in theological education, however, extends beyond effective transmission of content knowledge, cognitive development, and even development of thinking skills (Kilmurray, 2003) into the affective realm "found in terms such as moral development, formation, spiritual maturity, character, and other relatively intangible goals" (Patterson, 1996, p. 66). Although most believe you do not need to be in a mosque or a church to have direct contact with God, many believe that the interpersonal learning relationships that exist in the classroom help them draw closer to the divine. There is compelling interest from most religions of the world to find ways to use technology to extend educational opportunities without compromising the affective and spiritual growth and development of their members or students (Amos, 1999; Reissner, 1999; Baig, 2001; Patterson, 1996). This underlying interest of fostering and preserving affective and spiritual growth and development in the context of constantly changing political, economic, and religious environs will continue to influence the demand for distance learning by religious institutions. 


\title{
Examples of Distance Education Efforts
}

Figure 1. The Major Religions of the World as a Percentage of World

\author{
Religious Adherents as a \\ Percentage of World Population in 2002 \\ (adapted from www.adherents.com)
}

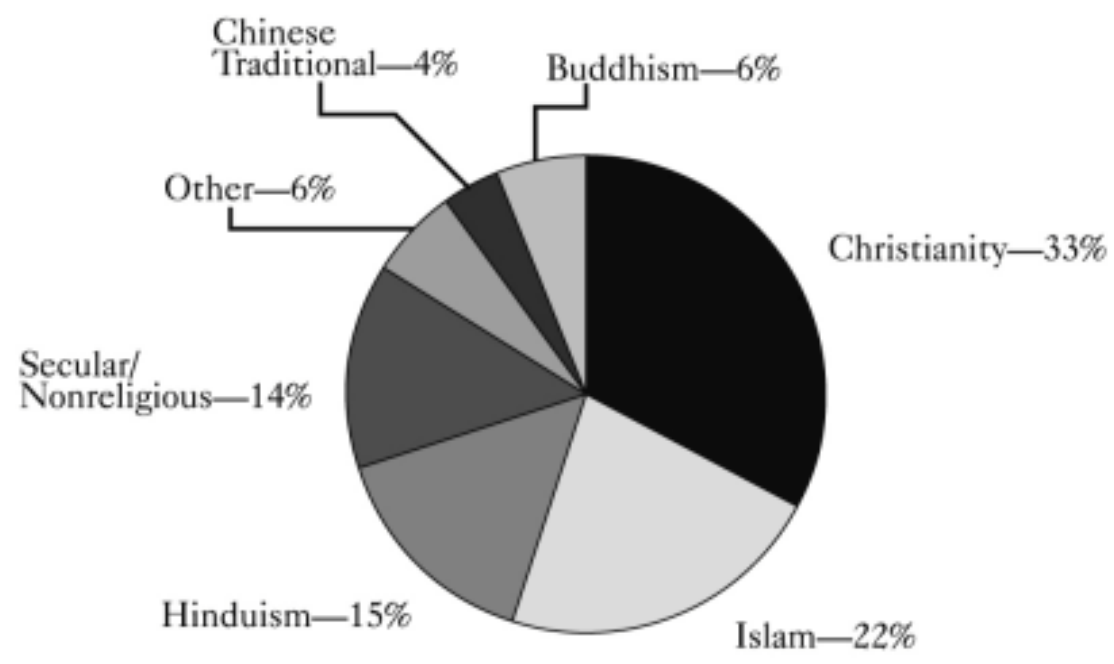

\section{Population}

In Figure 1, the majority of people on earth ascribe to some religion. The world's largest faiths are really conglomerations of smaller sects or denominations, which makes it difficult to deliver many specific statements which would hold true for the entire religion, especially about orientations to new technological innovations and opportunities afforded by distance education. For example, between China and Southeast Asia even the canon of Buddhist religious texts only overlap by approximately 10 percent (Dr. Lewis Lancaster, Personal Communication, March 16, 2004), so making any kind of definitive statements about the orientation of all Buddhists toward something like distance education is virtually impossible.

In addition, the world's religions exhibit varying degrees of decentralized authority. For example, within the Christian denomination of Presbyterianism, although the genesis of the denomination began with the French lawyer John Calvin (1509-1564), members today could be affiliated with independent Presbyterian churches within the U.S.A., the Presbyterian Church (U.S.A.) - which is a merger of 11,200 congregations and 21,000 ordained ministers (http://www.pcusa.org/navigation/whoweare.htm), or any number of Presbyterian churches that exist internationally - each autonomously governed. Although practitioners of certain faiths may have similar beliefs, there is not necessarily any governing authority over all of the independent congregations. This type of decentralization of governing authority is so common among the world's faiths that discovering all of the examples of adult distance education, much less ascribing motivations behind such efforts, becomes a difficult task indeed. 
In addition, educational institutions that might be expected to integrate faith and scholarship (e.g., Banares Hindu University, Israel Open University, Southern Methodist University) remain largely secular (aside from offering some religion courses), and some institutions that might be expected to be secular (e.g., American Open University) have faith as the foundation for their existence. Indeed, many secular institutions will offer courses on religion, even at a distance, but they are not the focus of this article. Confusion further arises as religious-based educational institutions (e.g., Moody Bible Institute) are founded by one who belong to the sponsoring religion, but not by the religion itself. Despite limitations such as these, the authors have researched and interviewed leaders and/ or academics representative of many of the world's largest faiths, especially those that seem more involved in adult distance education, and summarized some of the findings below. The interviewees were chosen because, when contacting the headquarters for a religious body (or universities associated with them), we were directed to these people as the person(s) who was/ were considered knowledgeable about that religion's distance education efforts. Still, the above-mentioned limitations, along with a host of other complexities, including changes in distance education models and technologies, should be considered when reading the following examples. Perhaps the most valuable thing the reader will gain is insights into how each religion is beginning to use the "concept" of distance education, or how the concept of distance education might figure into their overall orientation toward education.

The religions that are highlighted below were chosen mainly because of their size (Islam, Hinduism, Buddhism, and Christianity). Although Chinese Traditional religions make up four percent of the world's population, they are not discussed in depth because of lack of involvement in distance education. Both Judaism and the Baha'i faith with relatively fewer numbers of adherents are discussed, although in less detail, because of their international influence and integration of distance education. Because creating formal distance instruction is usually motivated by a religion's overall approach to education, each section begins by touching on the overall orientation to education in general. Although not every religion is represented, and the ones that are represented are only sampled, the adoption and integration - "conversion" - of distance education methods is evident in many religions of the world.

\section{Islam}

There are nearly 1.3 billion Muslims in the world today (Noss, 2003; or see http://www.adherents.com). Mamdouh Mohammed, of the American Open University, gave some reasons for Islamic interest in distance education. He spoke of the saying by Muhammad that seeking knowledge is an obligation by every Muslim, male or female (Personal Communication, 2004). Dr. James Badawi (2004) seems to indicate the same feeling. He said: "The Qur'an speaks highly of learning. The first word revealed of the Qur'an was, 'Recite,' or 'read.' As long as they were true to their faith, and to Qur'anic injunctions about learning, Muslims established a civilization that saw great advances in science and in the humanities" (p. 1). According to the

website for Federation of the Universities of the Islamic World (http://www.isesco.org.ma/English/Fuiw/index.asp), there are currently 193 Islamic-affiliated universities. Because of the emphasis on education and the growing availability of supporting telecommunication infrastructure, the likelihood of the growth and success of more Islamic-based distance education efforts in the future is very high.

Although the Islamic population is not only Arabic (and there are many Arabs of other faiths), integrating this type of education into Arab-Islamic society has not consistently been met with optimism. There are currently 58 member nations of the Organization of the Islamic Conference 
(OIC), which is the global intergovernmental organization of Islamic states (see http://www.islamicnews.org/english/index.html), each with different degrees of interest in and acceptance of distance education. According to Nasser and Abouchedid (2000) of Notre Dame University:

... in many Arab countries there has been no real implementation of distance education. Despite attempts by local institutions and international organizations like UNESCO to promote regional cooperation through distance education, Ministries of Education do not officially recognize higher education degrees obtained by distance in a number of Arab countries (e.g., Lebanon). Though the Arab Ministers of Education convened in the Lebanese capital, Beirut, on September 18, 2000, and announced the establishment of the Open Arab University in the year 2001, most education decision-makers remain militate against distance education. In fact, strategic thinking is counter weighted by negative attitudes towards the workability of distance education. While the battle for and against distance education goes on, neither policy nor basic research has examined the views and concerns of schoolteachers and directors towards the implementation of distance education programs in the Arab region (p. 1).

It is important to recognize that large Islamic populations exist outside of the Arab world in countries like Indonesia, Nigeria, and China. Despite the reluctance of some Arab-Islamic governments to embrace distance education, many other Islamic institutions still see it as a way to "develop applied sciences and use advanced technology within the framework of the lofty and perennial Islamic values and ideals"; "make Islamic culture the basis of educational curricula at all levels and stages"; and "safeguard the Islamic identity of Muslims in non-Islamic countries" (Islamic Educational, Scientific and Cultural Organization, ISESCO, http://www.isesco.org.ma/English/presentation/present.html).

Four of the main Islamic-affiliated distance learning providers are Allama Iqbal Open University, based in Islamabad, Pakistan; the Islamic American University (IAU), sponsored by the Muslim American Society; the American Open University; and the Arab Open University. Allama Iqbal Open University is primarily a distance teaching institution using multimedia techniques, correspondence packages, and radio and television broadcasts specially prepared for distance learners. The Arab Open University, based in Kuwait, is partnering with the Open University (UK) and UNESCO to provide quality distance education in that area of the world. Although they have just launched their program within the last two years, their plans include setting up university branches in a number of Arab countries, including Kuwait, Saudi Arabia, Bahrain, Jordan, Lebanon, and Egypt. ${ }^{4}$ There are also a number of independent Islamic universities (e.g., Sharif University of Technology [SUT] in the Islamic Republic of Iran) that are beginning to develop distance learning.

\section{Hinduism}

There are nearly 900 million adherents to the Hindu faith (http://www.adherents.com). Nobel Laureate Rabindra Nath Tagore called Hinduism the "Religion of Man," saying that the "Vedic" and "Veda" mean knowledge, and that the foundations of Hindu tradition are truly knowledge based. Gandhi advised his followers to consider how technological and economic progress would affect the poorest of the poor, and to see themselves as trustees and not owners of their financial and intellectual endowments (Swaminathan, 2001). 
Education has always been a core part of Hindu tradition, with temples and ashrams serving as centers of learning and teaching. Although previously the focus has been more spiritual training, more emphasis is now being placed on secular and sacred disciplines together, with Hindu-based organizations, like the Hindu University of America, emphasizing that the Hindu system has the ability of building "harmony amongst apparently conflicting things - secular versus sacred, science versus religion, etc.” (http://www.hindu-university.edu/).

India, the country with the largest Hindu population, has experienced external and internal influences, including secularism, which have subsequently limited the number of explicitly Hindu-sponsored institutes of higher education. The Hindu University of America, the Bhaktivedanta Institute of Science, and a few Veda colleges in the U.S. do offer degrees based on modern research and ancient wisdom taught at a distance. The Ayurvedic Academy in Seattle, Washington, offers distance education courses in Ayurveda to its students who can earn a Master of Hindu studies degree in Ayurveda, with significant course work available at a distance. Also, the Holistic Center in New York City, U.S.A., now offers an online two-year certification program in conjunction with Westbrook University. Graduates of this program can transfer credits toward a PhD in Ayurvedic medicine through Westbrook. In India, Sri Sathya Sai Veda Pratishtan (at Secundrabad) is setting up a Virtual Veda University. They have brought up all Veda-sakhas, sacred writings, including 96 Upanishads, onto the portal at www.vedamu.org. Additionally, the Hindu University of America has launched a distance education and correspondence program, currently offering Masters and Doctoral degrees in three areas (Hinduism, Hindu philosophies, and yoga philosophy and meditation). Although they are clearly still in the development stages, they remain optimistic about the future (Dr. Kuldip C. Gupta, Personal Communication, March 16, 2004). These notable examples of some Hindu-based distance education, while demonstrating use of distance education methods and technologies by some of the Hindu faith, should not be construed as a widespread integration among the Hindu religion.

\section{Buddhism}

Some consider the Buddhist tradition, now with 330 million adherents, as the first world religion to break free of one local area, spreading into other areas of the world, and the first to have sacred texts translated into many languages. Dr. Lewis Lancaster said: "When any technology comes along, it is easy to see how the philosophy that took Buddhism along trade or mercantile routes would take it through things like the fiber-optic cables of today" (Personal Communication, March 16, 2004). Although in some ways Buddhist groups are even more diverse than those in Christianity, Buddhists today are beginning to organize a much more global effort than even 50 years ago.

Similar to what is the case in Christianity, Buddhist societies have seen the formation of two types of educational institutions. One is the monastic colleges/ institutions (like Christian seminaries). In countries like Sri Lanka, teenage boys are required to attend monastic institutions for three months as a form of filial responsibility to their mothers. Following that period, each boy has the option of staying or leaving. In the 20th century (and even earlier in Japan) Buddhist groups began setting up institutions of higher education, the equivalent of any university in the West. There are currently dozens of these universities scattered across countries like Japan, Korea, Taiwan, Thailand, and Sri Lanka.

Faju University in Taiwan has a very active Web site (www.cbta.com), offering text-based online courses and providing online many of the Chinese Buddhist texts. As mentioned in the 
introduction, both in Thailand and Sri Lanka, there are some forms of correspondence courses in which anyone can take a test and receive a certificate that indicates they have learned the religious content. While there are not many Buddhist-affiliated degree-granting universities that provide distance learning, a new Buddhist college in Los Angeles, the University of the West, will stream its first course over the Internet to San Diego and the San Francisco Bay Area - and perhaps to Taiwan in summer 2004 (Dr. Lewis Lancaster, Personal Communication, March 16, 2004).

\section{Baha'i}

With nearly six million members (http://www.adherents.com), the Baha'i faith is also expanding its influence through distance learning. The Wilmette Institute was established in 1995 and is an agency of the Baha'i faith in the United States (http://www.wilmetteinstitute.org). The institute is dedicated to offering courses on Baha'i topics, both in its classrooms in Illinois and through distance learning; it is currently offering a dozen distance-learning courses per year with an average of 350 students from the United States and about 40 countries.

\section{Judaism}

Rabbi Joshua Heller at Jewish Theological Seminary confirmed that "Education is an essential value to Judaism," and this faith, comprised of nearly 14 million people, does "take education very seriously" (Personal Communication, February 17, 2004). The Kaminer Center for Distance Education is one example of Jewish-affiliated distance learning available to students, professionals, and lay people. This organization has online courses that offer access to interactive resources, a learning community, and contact with scholars and teachers from the Jewish Theological Seminary. There are also other Jewish organizations and universities that are experimenting with distance education.

\section{Christianity}

Having nearly two billion adherents, Christians, with their affiliated seminaries, colleges, and universities, have become the most active in using applications of distance learning. Zaleski (1997) reports that as early as 1997: "Christian websites made up more than 80 percent of the websites of the world's five major (i.e., most influential) religions” (p. 99). Interestingly enough, the educational institutions sponsored by Christian churches rank among the largest sponsors of these websites. The Christian emphasis on education is also reflected in the literally thousands of institutions of higher education (colleges and universities) that are Christian affiliated and/ or sponsored.

Pope John Paul II in his message at the XXXV World Communications Day (May 27, 2001) encouraged the use of the "positive capacities of the Internet to carry religious information and teaching beyond all barriers and frontiers" (p. 2). When making the official announcement about the debut of the Catholic Information Center on the Internet (CICI), the Archbishop Martino said: "For the Church to fulfill her mission of teaching and serving all mankind, it is appropriate she make use of technology that offers the possibility of immediate, in-depth communication with the entire world" (as quoted in Zaleski, 1997). For a long time, this vision of being able to reach beyond all barriers and frontiers, increasing opportunities to bless the world with education, locally or internationally, has been one of the motivations of the many Christian pioneers of multiple denominations who have ventured forward past known horizons into what they have 
hoped to be the promised land of distance learning. Although there are questions arising in the Christian literature (Reissner, 1999; Patterson, 1996), some fervently arguing that distance learning is an unsuitable medium for true Christian education (Crosby, 1997), there is undoubtedly a large and growing number of Christian-affiliated formal adult distance learning programs. Baker's Guide to Christian Distance Education profiles up to 150 Christian distance degree programs. Outlined below are only a few examples of the growing number of these programs.

- The Catholic Distance University (CDU) has enrolled over 10,000 students in its correspondence courses since 1983, and is now launching an online program (Retrieved on March 3, 2004, at http://www.cdu.edu/courses programs.aspin). Additionally, 25 Jesuit-affiliated universities have collaborated to create a type of virtual university, www.Jesuit.net, which currently offers 190 online courses in 35 programs to approximately 8,500 students each year (Dr. Richard Vigilante, Electronic Communication, March 3, 2004).

- The Seventh-Day Adventists church has founded one of the oldest (1909) distance education programs in the world, Home Study International (HSI). In 1990, HSI renamed its collegiate division Griggs University, enrolling 950 students in 113 undergraduate independent study courses in 2003, of which 10 percent are computer-based (Dr. Joseph Gurubatham, Personal Communication, March 15, 2004). Also in January 1999, the Adventist Virtual Learning Network (AVLN) consortium (www.avln.org) created a Web portal, http://www.sdaedu.org/, called the Adventist Distance Education Consortium (ADEC), now offering over 124 courses from Adventist-affiliated universities/ colleges.

- Because their evangelic mission statement has such a strong emphasis on reaching out to the communities they serve, the Assemblies of God church has created an extensive distance education provider called Global University. Global now offers courses to more than 178 countries around the world, in more than 145 languages through Internet, correspondence, and international study centers. All higher education enrollments, from institute level to Masters level, comprise 580,000 students (Thomas Harrison, Personal Communication, March 17, 2004).

- The Church of Jesus Christ of Latter-day Saints has recently begun a series of worldwide leadership training broadcasts. The central leadership of the church trains lay-clergy in nearly 200 countries via satellite broadcasts, simultaneously translated into over 50 languages. These training sessions are streamed over the Internet and subsequently distributed on DVD to local leaders for review and further training. Resources are also being contributed towards Web-based training for lay clergy and members. This church's main institution of higher education, Brigham Young University (BYU), began its correspondence program in 1921. Seeing a strong connection between faith and reason, spiritual and secular education, it is one of the largest correspondence programs of its kind in North America, enrolling 26,751 adult students during 2003, with 146 of the 301 paper-based correspondence courses now available on the Internet.

- Seminary Extension, a ministry effort of the six theological seminaries of the Southern Baptist Convention, states as its mission as providing "the delivery of Biblical, Theological, and Practical education to Christians wherever they live via Internet, CDROM, local live classrooms, and correspondence.” Nearly 4,000 students take Seminary Extension courses either through the 500 Extension Centers (via live classrooms or classes on the Internet) and/ or through independent study (via correspondence, CD- 
ROM, and Internet). Additionally, in 2003 over 600 Florida Baptists participated in theological education in Florida through classes offered by the Baptist College of Florida (BCF) and New Orleans Baptist Theological Seminary (NOBTS) (Denman, 2004).

- In 1993, the Evangelical Lutheran Church in America (ELCA) issued a statement of eleven Imperatives for Theological Education (http://www.elca.org/dm/te/appendix_c.pdf retrieved March 12, 2004) that encouraged the seminaries to develop theological education for all members. This mandate spurred the eight seminaries of the ELCA, the Private Financial for Lutherans, and the Augsburg Fortress Publishers to combine their efforts to create The Fisher's Net. This strictly e-learning provider currently has around 2,000 users who participate in semester-long classes that contribute to degrees or certificates (Arne Selbyg, Personal Communication, March 5, 2004).

- Beyond these examples, both Southern Christian University (SCU) and the Moody Bible Institute (MBI) are making considerable contributions in distance learning. SCU is partnering with the U.S. Department of Education and 14 other institutions of higher education and consortia to develop models designed to help enhance access to federal (U.S.) student aid for distance education-based programs. MBI, founded in Chicago in 1886, formed a correspondence department in 1901. It continues today with a total of over one million enrollments since its inception (Schlosser and Simonson, 2002). It began offering online courses in 2000, growing from 241 online enrollments in its first year to 1,130 enrollments between June 2002 and June 2003 (Sarah Peeler, Electronic Communication, February 25, 2004).

\section{Future Trends and Research}

Despite some setbacks and skeptics, most of the religious leaders and scholars we interviewed remain optimistic about the future uses of distance education by religious institutions. Large faithbased distance learning efforts will likely continue with more collaborative agreements between the religious-affiliated universities and seminaries and/ or religious organizations that are fairly centralized and place a strong emphasis on education. These efforts will be focused on training clergy and providing degree-seeking university students of faith more flexibility in higher education and lifelong learning. At the same time, however, there will be a general increase of interest in and use of distance learning via the Internet or WWW for certain religions, only as the host countries build out their technological infrastructure and become more politically supportive.

The authors also predict that as globalization increases, state-sponsored institutions of higher learning will become more pluralistic and secular. This will likely create an increased demand for more faith-based education, which seeks to integrate spiritual and secular learning. Religioussponsored distance education providers will also continue to struggle with the more common questions and concerns of when to use distance education, types of pedagogical models, desired outcomes, choices of technology, and financial implications.

Since the use of distance learning by religious institutions is a relatively unexplored and unresearched area, the authors encourage further scholarly inquiry into the issues and practices surrounding it. Experimentation by religious-based distance education providers in emphasizing the affective and spiritual, as well as the cognitive domains of learning, holds significant promise.

The authors acknowledge that each major religion was discussed only briefly. As such, they encourage more in-depth research on each religion's use of distance education. This research will 
then contribute to a growing body of literature that will assist religious institutions in identifying best practices in distance education implementation, especially in their efforts to weld and integrate the secular and spiritual together as they reach out to train, edify, and educate their adherents. As more religious institutions articulate and share their educational mission, a clearer picture of the diversity, versatility, and role of faith-based distance education will also emerge. Finally, the authors encourage further inquiry into the larger role religious education - including distance education - may have in promoting not only the spiritual development of the individual, but also of society.

\section{Conclusion}

Although it is difficult to identify and classify all the different approaches, attitudes, applications, and functions of religion on and in cyberspace (Karaflogka, 2002), it is clear that formal adult education at a distance is receiving increased attention by most of the world's largest religions. Even though these major religions differ in their theology and are influenced by a number of unique religious, economic, and political factors, many Islamic, Hindu, Buddhist, Baha'i, Jewish, and Christian leaders and scholars value the potential role distance education may have in assisting them in achieving their institutional mission. Ultimately, as an official at a Buddhist monastery in Tibet summarized, cyberspace has been designed in such a way that there is an absence of obstructions. "[This] creates the potential for something to arise. And the nature of what will arise there is dependent on the motivations of the people that use it" (Thomas E. Miller, as quoted in Zaleski, 1997, p. 280). Zaleski (1997) insightfully reflects that in a similar way to how our souls become what we make of them, "so will the soul of cyberspace, for cyberspace mirrors us in our entirety” (p. 281).

Reflecting in this mirror is the value many religious institutions place on the availability and quality of adult distance education programs. This reflection is shown in the increasing number of distance education programs and, perhaps more importantly, the sincere, searching questions developers are asking about how distance learning should be best used. Distance learning has allowed many religions to extend the reach of their seminaries to train clergy and for some to extend the reach of their affiliated universities to provide educational opportunities to their membership. In particular, distance learning has opened up many opportunities, previously unavailable, in reaching out in a way that is able to strengthen followers' faith within "the social context in which a student lives” (Schlosser and Simonson, 2002, p. 10).

The greatest educators throughout history (e.g., Confucius, Socrates, Mohammed, Jesus, and others) have ultimately seen education as most valuable in developing more than just what we know and what we can do, but especially in how that expanded knowledge and ability contribute to who we become, developing each individual and society in ways that best contribute to the good, the true, and the beautiful. Although many religions of the world and their affiliated institutions are still experimenting with different methods and media in using distance education, perhaps it will be the faith-based institutions that lead the way in discovering how to use distance learning most effectively in teaching "how to live," not merely in teaching "how to make a living."

\section{Terms and Definitions}

Affective - Domain of learning concerned with inward disposition, feeling, intent, intention, earnest, reality; contrasted with merely cognitive development and/ or external manifestation. 
Clergy - The clerical order; the body of men and women set apart by ordination for religious service in a church; as opposed to laity.

Collegiate Ministries - Religious administrative structure of a university; ministerial administration of degree-seeking colleges and universities.

Correspondence Education - The form of distance education that is paper-based; communication between teacher and students is by correspondence, not face-to-face.

Laity - The condition or state of a layman, the body of the people not in orders; as opposed to the clergy.

Piety - The quality or character of being pious; habitual reverence and obedience to God (or the gods); devotion to religious duties; godliness, devoutness, religiousness.

Pluralistic - Of or belonging to a pluralist or to pluralism; recognizing more than one ultimate principle in existence or being as contrasted to monism.

Religious Institutions - Organizations, including some universities and colleges, that are affiliated with or sponsored by a religious organization.

Seminaries - Schools or colleges created to educate persons for the practice of ministry and/ or for teaching and research in the theological disciplines.

Theological Education - Education that is mainly on spiritual topics, preparing persons for the practice of ministry and/or for teaching and research in the theological disciplines.

\section{References}

Amos, K. E. (1999). Report of the Survey of ATS Schools on Educational Technology and Distance Education. Theological Education, 36(1), 125 - 140.

Badawi, J. (2004). Bridge Building Between Christians and Muslims. IslamiCity. Retrieved January 20, 2004 from: http://www.islamicity.com/Mosque/Bridge.shtml

Baig, K. (2001). What Is Wrong with Our Education System? Retrieved March 10, 2004, from: http://www.albalagh.net/education/

Bellinger, C. K. (2003). Reflections on Distance Learning and Theological Pedagogy. Retrieved February 11, 2004, from: http://www.wabashcenter.wabash.edu/Internet/SWATLA2003.html

Cannell, L. (1999). A Review of Distance Education. Theological Education, 36(1), 1 - 72.

Church Executive (2004). Top 25 U.S. churches list now includes four Pentecostal bodies. March 16, 2004 headline from Church Executive website. Retrieved March 20, 2004 from: http://www.churchexecutive.com/News.asp?Article=1694 
Crosby, J. F. (1997). Doubts about DE that won't go away. Response to Dr. Miletic. The University Concourse, 3(3). Retrieved October 22, 2004 from:

http://www.theuniversityconcourse.com/III,3,12-9-1997/Crosby.htm

Denman, B. (2004). Theological education includes on-line courses. Florida Baptist Witness, 121(28). Retrieved July 29, 2004, from: http://www.floridabaptistwitness.com/2891.article

Gupta, K. C. (March 16, 2004). Personal Communication. Professor at the Hindu University of America.

Gurubatham, J. (March 15, 2004). Personal Communication. President of Griggs University.

Harrison, T. (March 17, 2004). Personal Communication. Associate VP U.S. Student Relations for Global University.

Helland, A. C. (2002). Surfing for Salvation: Organized religious participation on the Internet. RELIGION, 32(4) 293 - 302.

Heller, J. (February 17, 2004). Personal Communication. Rabbi. The Jewish Theological Seminary.

Hillerbrand, H. J. (2004). Encyclopedia of Protestantism. New York: Routledge.

Hinckley, G. B. (2001). A Prophet's Counsel and Prayer for Youth. New Era, 4(1) 4 - 15.

Johnson, S. (March 8, 2004). Personal Communication. Director of Collegiate Ministries. United Church of Christ.

Karaflogka, A. (2002). Religious discourse and cyberspace. RELIGION, 32(4) 279 - 291.

Kilmurray, J. (2003). E-Learning: It's more than automation - Commentary. Retrieved February 11, 2004, from: http://ts.mivu.org/default.asp?show=article\&id=1014

Lancaster, L. (March 16, 2004). Personal Communication and Electronic Communication. President of the University of the West.

Lin, J. (2004). The Foundation of Taoist Philosophy and Its Implication for Education. CIES Conference Presentation. Salt Lake City, Utah.

Lin, J. (2004, March 28) Personal Communication. CIES Conference.

McFarland, S. (1998). Communism as Religion. International Journal for the Psychology of Religion, 8(1), 33.

McLoughlin, C., and Luca, J. (2003). Quality in Online Delivery: What does it mean for assessment in e-Learning environments? Retrieved August 31, 2004, from: http://www.distance$\underline{\text { educator.com/dnews/modules.php?op=modload } \& \text { name }=\text { News } \& \text { file }=\text { article } \& \text { sid }=8595}$ 
Mohammed, M. (February 17, 2004). Personal Communication. American Open University.

Nasser, R., and Abouchedid, K. (2000). Attitudes and Concerns towards Distance Education: The case of Lebanon. Online Journal of Distance Learning Administration, 3(4). Retrieved October 22, 2004 from: http://www.westga.edu/ distance/ojdla/winter34/nasser34.html/20/2004

Noss, D. S. (2003). A History of the World's Religions. Upper Saddle River, NJ.: Prentice Hall.

Patterson, E. (1996). The Question of Distance Education. Theological Education, 33(1), 59 - 74.

Pope John Paul II (2001). Address given for the Pontificium Consilium e Communicationibus Socialibus, Message of the Holy Father for the XXXV World Communications Day, Sunday, May 27, p. 2.

Peeler, S. (February 25, 2004). Electronic Communication. Moody Bible Institute.

Reissner, A. (1999). An Examination of Formational and Transformational Issues in Conducting Distance Learning, Including Issues Related to Faculty Development. Theological Education, 36(1), 87 - 100.

Schlosser, L. A., and Simonson, M. (2002). Distance Education: Definition and glossary of terms. Definitions and Terminology Committee Association for Educational Communications and Technology. Retrieved January 6, 2004 from: http://www.aect.org/Intranet/Publications/Disted/Disted.asp

Selbyg, A. (March 5, 2004). Personal Communication. Director for Colleges and Universities, Evangelical Lutheran Church in America.

Stewart, J. (February 9, 2004). Personal Communication. Dean of the School of Distributed Learning. Bethany College.

Swaminathan, M. S. (2001). Universities and bridging the divide. The Hindu, Online edition of India's National Newspaper. Monday, June 11, 2001.

Vigilante, R. (March 3, 2004). Personal Communication. Executive Director. JesuitNET.

Yildiz, I. (March 5, 2004). Personal Communication. Chair of the Department of Philosophy and Religion at the University of Yuzuncu Yil in Van, Turkey.

Zaleski, J. (1997). The Soul of Cyberspace: How New Technology Is Changing Our Spiritual Lives. New York: HarperCollins Publishers, Inc.

\section{Endnotes}

1. Words appearing in boldface are defined in the glossary.

2. The church's training of its own workforce, outside of the clergy, is another small beneficiary group of some formal distance education instruction, but this is not addressed in this paper. 
3. This can include providing courses and instruction for parents who are teachers, particularly in the U.S., where home study is heavily influenced by religion to insulate children from secular or social evils while inculcating religious doctrines and values. Most of the time, however, this type of instruction is informal and facilitated by newsletters, online support communities, etc.

4. One of its missions is to "instill in its students the spirit of upholding deeply rooted social and ethical values of the Arab-Islamic heritage, and an appreciation for other human cultures and heritages" (http://www.arabou.org/c1.htm). 